\title{
An Analysis of the Potential Use of Public-Private Partnerships in Water Infrastructural Development in Zimbabwe: The Case of Harare City Council
}

\author{
Hudson Mutandwa \\ Department of Political and Administrative Studies, Faculty of Social Studies \\ University of Zimbabwe \\ P.O.Box MP 167, Mount Pleasant, Zimbabwe \\ Email: hbkmutandwa@gmail.com
}

Tawanda Zinyama

Department of Political and Administrative Studies, Faculty of Social Studies

University of Zimbabwe

P.O.Box MP 167, Mount Pleasant, Zimbabwe

Email: tzinyama@ sociol.uz.ac.zw

Accepted: March 22, 2015

Doi:10.5296/ jpag.v5i1.7366 URL: http://dx.doi.org/10.5296/ jpag.v5i1.7366

\begin{abstract}
The study was carried out to analyse the potential use of Public Private Partnerships (PPPs) in water infrastructural development in Harare City Council, Zimbabwe. PPPs play a pivotal role in water infrastructural development if fully implemented. Zimbabwe's rate of uptake is low. There are preconditions that are necessary for successful implementation of PPPs inter alia political will (commitment) legal, institutional and political frameworks. Key informant interviews and documentary search were employed to gather data. The study established that Zimbabwe does not have the preconditions necessary for successful implementation of PPPs and this confirms the thesis. The main challenges include lack of legal and institutional framework, lack of political will, unconducive socio-economic environment. Zimbabwe's water infrastructure is ramshackle. This is compounded by lack of fiscal space on the part of government to rehabilitate the infrastructure. PPPs could be a viable alternative to infrastructural development with the right environmental conditions.
\end{abstract}


The study recommends that the government should quickly enact a PPP legal framework that enables the establishment of a PPP unit within the Ministry of Finance and this should be followed by an Act of Parliament which should institutionalize PPPs. The Government should promote a conducive investment climate.

Keywords: Public-private partnerships, Harare City Council, infrastructural development

\section{Introduction}

The possibility of using public private partnerships (PPPs) in delivering clean water for domestic and industrial use in Zimbabwe has hardly been investigated. In many countries, PPPs are being used for the delivery of water. Across the globe, interest in PPPs as an instrument for delivering water is gaining momentum because PPPs offer solutions to the development of infrastructure. PPPs allow governments to expand the provision of services by using the market tools (ADBI 2011: 4). Thus, PPPs create efficiency and effectiveness in service provision as well as creating commercial value. Zimbabwe is among those countries that are faced with limited fiscal space with an outstanding debt of more than US10 billion dollars to both domestic and international creditors (GoZ Budget Statement 2012, Zhou 2012: 34). Public utilities and service provisions are deteriorating. Its readiness to harness PPPs is what this research seeks to establish. The rationale for adopting the PPPs is often limited public funds compounded by an increasing acceptance that the private sector is often better able to handle many of the traditional tasks of the public sector.

According to the ADBI (2011:5), the private sector has shown better ability in providing quality and efficient public services. ADBI further notes that PPPs provide additional capital, better management and implementation skills, and adds value.

Therefore, this research seeks to analyze the potential use of PPPs in the development of water infrastructure in Zimbabwe. Zimbabwe's water and sewerage infrastructure is in a sorry state (Dube and Chigumira 2011: 15). For example, the City of Harare's water infrastructure is dilapidated and forty (40) percent of treated water is lost through leakages (ZNCC, 2009). The Morton Jeffry Water Works which is the main water source for Harare is dilapidated and can no longer cope with the ever growing population. The Zambezi Water Project proposed more than 100 years ago has not been implemented despite perennial water shortages in Matabeleland Region. Any water projects like Tokwe-Mukosi Dam in Masvingo, Kunzvi Dam in Harare and Zambezi Water Project have not been completed due to limited fiscal space. PPPs help in complementing government efforts in infrastructural development of such kind, helping in irrigation development, urban water supply and sewerage reticulation, water for sporting facilities and for industrial use.

\section{Objectives of the study}

- To analyze whether PPPs as an intervention can help in the provision of water infrastructure for such uses as irrigation, water sports, domestic and industrial use.

- To understand the legal, institutional, structural and political frameworks necessary 
for the success of PPPs and assess whether Zimbabwe has these factors in place.

- To investigate the challenges being faced by Zimbabwe that hinders effective implementation of private public partnerships in water infrastructural development.

- To proffer recommendations for Zimbabwe to fully engage private public partnerships in water provision.

\section{Research questions}

1. Can public private partnerships be helpful in the provision of water infrastructure in Zimbabwe?

2. What are the legal, institutional, structural and political frameworks that govern PPPs in the provision of water in Zimbabwe?

3. What are the preconditions necessary for public private partnerships in water and do they exist in Zimbabwe?

4. Is Zimbabwe ready for PPPs in general and water PPPs in particular?

5. What are the challenges being faced by Zimbabwe that hinder effective implementation of public private partnerships in water infrastructural development?

6. What are the strategies that Zimbabwe should put in place to fully engage public private partnerships in water provision?

\section{Justification of the study}

This study derives its importance from the fact that an analysis such as the one conducted here has not been conducted for any kind of PPP in Zimbabwe. The results of this research will be readily available to other researchers who are also interested in studying Zimbabwe's potential use of PPPs in water infrastructure and other areas. Conclusions and recommendations from this study may also be helpful to policy makers and implementers of PPPs in Zimbabwe. At the core of potential use of PPPs is lack of fiscal space by governments. In contrast, the private sector offers efficiency, effectiveness and managerial skills which increase project delivery at a limited cost. It is a common phenomenon that most governments enter into partnerships not by choice but by difficult circumstances. This study will contribute knowledge to governments and development partners.

The study takes a case study approach. Integration of other methodology will be used to produce well balanced realities on the potential use of PPPs in water infrastructure development in Zimbabwe. To date very limited academic research on the potential use of PPPs has been carried out in Zimbabwe. This research draws some lessons from other countries such as South Africa (SA), United Kingdom (UK), the Philippines among others which have successfully implemented PPP projects. The study of this nature will be important for Zimbabwe's policymakers. This study tries to fill in the gap of limited literature on PPPs in water infrastructural development. The study is also of importance in that it is being carried out at a time when Zimbabwe is facing limited fiscal space to maintain its dilapidated 
water infrastructure.

\section{Literature Review and Theoretical Framework}

This section looks at the existing body of literature on Public-Private Partnerships (PPPs) in both developing and developed world. It generally represents origin, existing gaps as well as new developments experienced in this discipline. The section comprises the following subtopics and subthemes: Definition of concepts, the genesis of PPPs, Operational Models, prerequisites of PPPs in water infrastructural development, the virtues surrounding PPPs in Water Infrastructural Development, Global Experiences of PPPs in Water Infrastructural Development.

\section{Conceptual Framework}

\section{Public-Private Partnerships (PPPs)}

The concept of PPPs is evidently well documented in literature, but with different definitions. That is why Public Accounts and Estimate Committee report (2006: 37) states that despite that the term Public-Private Partnerships has been in general use since 1990s, there is no widely agreed single definition or model of PPPs. Pollit and Bockaert (2000) further state that the term Public Private Partnerships, while universally used, has different contemporary meanings and manifestations.

According to Dube and Chigumira (2010:11) the concept of PPPs entails "contracts" between a public sector authority and private party, in which the private party provides a public service and assumes substantial financial, technical and operational risks in the project. Similarly, Partnerships British Colombia (2003) defines PPPs as "legally binding contract" between government and business for the provision of assets and the delivery of service that allocates responsibilities and business risks among the various partners. These contracts generally formalises collaborative efforts by both the government and business players to refurbish dilapidated public infrastructure. In this context PPPs are an agreement between a government and a private firm under which the private firm delivers an asset, a service, or both in return for payments contingent to some extent on the long term quality or other characteristic of output delivery (The World Bank 2007:11).

Omoyefa (2008:17) views PPPs within the public sector management reform as "...total overhauling of government administrative machinery with the aim of injecting real effectiveness, efficiency, hard core competence and financial prudence into the running of the public sector." This rebranding of the public sector is targeted to meet the demand of a rapidly improving and changing global socio-political environment. Fourie and Burger (2000) define PPPs as an institutional and contractual partnership arrangement between government and a private sector operator to deliver a good or service to the public.

A commonality in these definitions is that the concept of PPPs is largely discussed as a gap-filler towards infrastructural development by government. It must be noted that, however, the punch of PPPs in infrastructure projects largely depends on the extent to which the government effectively controls the private partners sufficiently providing operational 
autonomy for private partners

\section{Genesis of PPPs in Infrastructural Development}

The evolution of PPPs can be traced back to the period of the 1970s during which macro-economic dislocation ensued. The trajectory of PPPs is found in the New Public Administration (NPM) body of reforms in which there was a stubborn retreat of government frontiers in the provision of public goods and services. In this respect, the PPPs were seen as the gap-filler of the recurrent government failure. According to Mcquaid and Scherrer (2009:2) United Kingdom (UK) has been a leader in the large scale introduction of PPPs. To Ball et al. (2002) between 1987 and 2006 the UK government had signed 590 PPPs by the Conservative government through Thatcher's theme of 'draining the swamp'. In Zimbabwe according to Dube and Chigumira (2011:3) the idea of PPPs was mooted in 1998 and significant attempt to craft a PPP framework was done in 2004. However, up to now the legal and regulatory frameworks of PPPs are yet to be established although some PPPs projects have been implemented in the country, namely the Beitbridge-Bulawayo Railway (BBR), the New Limpopo Bridge (NLB) and the Newlands Bypass (Zimbabwe National Chamber of Commerce 2009). Recent years have seen a marked increase in cooperation between the public and the private sectors for the development and operation of infrastructure in a wide range of economic activities. Such PPP arrangements were driven by limitations to cover investment needs but also by efforts to increase the quality and efficiency of the public service.

The evolution of water PPPs can be traced back to the 1990s when many governments embarked on ambitious reforms of their urban Water Supply and Sanitation (WSS) services (Marin 2009:1). Since 1990 more than 260 contracts were given to private contractors for the management of water and sanitation in developing countries and most of these projects were in the form of Build Operate and Transfer (BOT) models. Ibid further alludes that between 1991 and 2000 over 94 million people received water from private operators. By the end of 2007160 million people were served by private operators which marked increase in water PPPs in developing and developed countries. Countries such as Algeria, China, Malaysia and Russia engaged the private water operators on a large scale. In developing countries in particular the evolution of water PPPs can be traced back to the $19^{\text {th }}$ and $20^{\text {th }}$ centuries (Marin 2009: 17).

Urban water systems in many cities of the Americas and Europe as well as in colonies were financed by private firms. Water infrastructure in countries such as Chile, New Zealand and the UK has been privatized in the 1980s. The rationale was that the private operator can operate more efficiently because of its profit motive and the fact that its contract contains clear, consistent objectives and means rather than multiple and often conflicting goals assigned to state owned utilities (Harris 2003). The 1990s witnessed massive development of water PPPs. Countries such as Argentina, Bolivia, Venezuela and Colombia in Latin America undertook water reforms from the 1980s. However, in Africa Cote d'Ivoire was an exception as it undertook private operator called Societe d' Amenagement Urbain et Rural (SAUR) since 1960 and operated the national private water utility called Societe de 


\section{Mll Macrothink}

Journal of Public Administration and Governance ISSN 2161-7104 2015, Vol. 5, No. 1

Distribution de Cote d'Ivoire (SODECI) under the affer-mage contract. Different countries started water PPPs at different times.

\section{Models of PPPs in Water Infrastructural Development}

In literature there are myriad of models that seek to explain how PPPs can be applied to suit government's infrastructural networks whilst respecting their context specific factor. These models include Build- and- Transfer scheme (BT), Build- Operate- and- Transfer scheme (BOT), Build-Own-Operate-and- Transfer scheme (BOOT), Build-Lease- and Transfer (BLT), Build- Transfer- and Operate (BTO), Rehabilitate- Operate and Transfer (ROT) and LeaseDevelop and Operate (LDO) (Dube and Chigumira 2011:2).The Nepal Planning Commission Paper (2009:8), highlighted the same PPP models but added the develop-operate and transfer (DOT) model. ADBI 2011:19) included the design build finance and operate (DBFO) model. This paper specifically focuses on BOT and DBFO as PPP models to appreciate how the concept of PPPs can be fully utilised in Water infrastructural development.

\section{Built and Transfer (BT) Scheme}

The underlying principle of this scheme is that, the private sector provides finances to construct the infrastructure and then hand over the facility to the government upon completion. The government would then pay back the agreed finances as agreed and the private player gets reasonable returns. The possibility of using this scheme in water infrastructural development is visible especially in dam construction, waterworks and sewer reticulation plants.

\section{Build-Operate-and-Transfer (BOT)}

The build-operate-and-transfer provides that the private sector constructs the infrastructure, operates the facility and maintain it. The private sector operates the facility for an agreed fixed term. The private is then allowed to impose the user-fees to the users of the infrastructure. This allows the private player to recoup the costs including some profits. The facility is then handed over to the public authority at the end of the fixed term, for example 20 or so years. In water infrastructural development, the BOT model can be of use since water is marketable; it is easy to put user-fees to the users of this commodity.

\section{Build-Own-Operate-and Transfer (BOOT) Model}

Implied here is that, the private sector finances, constructs, owns and operates the facility for a fixed term. In this scheme, the private sector is allowed to own the infrastructure during the tenure without prejudice and recovers its costs including profits through user-charges. The infrastructure is then handed to the government or government department after the agreed term. In water infrastructural development, the scheme suits quite well since the private player can develop dams, water treatment plants and introduce user-fees for an agreed term.

\section{Build-Lease-and-Transfer (BLT) Model}

The model presupposes that, the private players construct the infrastructure and upon completion, the infrastructure is leased to the government or government agency. It is during 
this lease period where the private player recoups its costs and gains reasonable proceeds from the government or government agency for an agreed term. The government then assumes ownership and control over the facility after the agreed term and stops paying the lease. In water infrastructural development, the model can apply since governments are faced with limited fiscal space to fund infrastructural development.

\section{Build-Transfer-and-Operate (BTO) Model}

Similarly, the private sector finances the construction of the infrastructure and transfers it to the government upon completion. The private player then operates the facility on behalf of the government and proceeds are shared as per contract agreement.

\section{Rehabilitate-Operate-and-Transfer (ROT) Model}

Implied in this model is that, the infrastructure exists but is dilapidated. The private sector refurbishes, maintains and renovate the facility. The same private player is allowed to operate the infrastructure for an agreed period. It is during this period where the private player earns returns from the investment. The facility is then handed back to the government body or agency. In Zimbabwe water infrastructure, the position is that the facilities are in a sorry state and demands massive rehabilitation. For example the Morton Jeffry Water Works, the Chitungwiza Aquatic Complex Swimming facilities, Irrigation facilities only to mention but a few are in deplorable state. This scheme could fit in quiet well. The government does not have enough resources to do it alone.

\section{Lease-Develop-and-Operate (LDO) Model}

The model works as follows, the private player leases an existing facility form the government, renovates, modernises, or expands it before assuming operation rights for a fixed term. The company recoups its costs through operation and government benefits through lease payments.

An analysis of the above models indicates two basic categorise and these include new projects and already existing projects. From these two categories, water infrastructural development requires both rehabilitation of the already existing infrastructure and also building of new projects. Dam construction, water treatment plants, pipes, irrigation schemes is possible under these categories. However, for the purpose of this study the researcher shall use BOT and DBFO. According to ABDI 2011.19) "BOT is suited to projects involve a significant operating content particularly water and waste projects and DBFO is suited to projects that involve a significant operating content particularly suited to roads, water and waste projects." The strengths of BOT include transfer of operating risks, construction and design and it has the capability to speed-up construction. It also promotes innovation of the private sector as well as improving value for money. BOT improves the quality of operation and maintenance. It has also the advantage of off-loading the government workload so that it concentrates on its core public sector responsibilities. DBFO has the advantages of attracting private sector finances and debt finance discipline. It also delivers more predictable and consistent cost profile. Further, increased risk transfer in DBFO provides greater incentive for private sector contractor to adopt a whole life costing approach to design. 


\section{Pre-requisites for Successful Adoption of PPPs}

The world over successful PPPs largely depends on conditions which serve as bench marks for proper implementation. Without these pre-conditions, implementation of PPPs becomes problematic. Pre-conditions of PPPs are relatively similar in context but vary from one country to another. In some countries such as the European Union preconditions are well spelt out in the European Commission guidelines. But countries are not forced to take those preconditions. Chief amongst the preconditions for successful implementation of PPPs are not limited to the following, legal and Institutional framework, political will, financial support, economic stability, technical expertise, public acceptance, respect of property rights and government commitment

According to the ADB handbook the legal, regulatory and policy frameworks presents a benchmark for establishing PPPs. There is need for a country to create a policy framework for PPP activity and regulation. The legal framework helps in establishing the legal reforms needed to reduce impediments to improved or expanded service such as assignments of responsibility for development, control lines, financing, regulating and managing infrastructure assets. It is also important to note that realistic legal reforms are needed to overcome potential constraints to PPPs including inhibiting asset ownership or management, repatriation of resources and barriers to cost recovery. The legal framework is important in PPPs in that it regulates and monitors service obligations, compliance with service conditions, consumer protection, tariff regulation and asset management, there is need to develop a PPP process that is consistent with the legal and regulatory regime. Further, there is need to develop a PPP regulation that seeks to address perceived gaps in the legal and regulatory framework.

The institutional and capacity status entails that there should be proper assignment of the appropriate level of authority to institutions and even creating new institutions that regulate PPPs. These new institutions must be composed if well educated in order to train new roles to staff to perform new functions and developing manuals, procedures standards and other tools required to implement new functions. The commercial, financial and economic issues highlights that there is need to agreeing with the stake holders on the economic balance of costs and benefits to be achieved in the sector reform. There is need to develop a financial plan for PPP that is realistic for the market and is commercially viable. The technical aspect entails defining and documenting the desired technical outcomes of the partnerships. Further it defines the correct metric for measuring improvements, achieving improvement, achieving the investment and documenting the expected improvements which do not require major investment.

In a nutshell the road map to PPPs includes; strategic planning, organising and managing the process, collecting additional information, defining objectives, resolving constraints, defining scope, selecting options, identifying partners, financing for investment, cost recovery strategy, regulatory strategy, finalising the terms of the partnership, tendering and procurement, negotiating and contracting, managing the contract, monitoring and evaluation, managing disputes and managing transition 
Edwards (1980:147) elaborates that "in implementing as well as formulating, accommodation must be made to political interests, scarcity of resources, and the nature of our bureaucracies and our political systems." The political environment ought to be conducive for PPPs. Van Horn and Van Meters (1974:30) argues that implementation of public policies needs political support. For Fervrier (2003:7), preconditions for successful PPPs include establishing PPP structures, legal and regulatory structures, financial and economic implications, integrating grant financing and PPP objectives and conception, planning, implementation of PPPs. In addition the Nepal planning Commission elaborates on firm government commitment, creation of a separate autonomous high level body to deal with PPP issues, conducive policies and Acts and sharing of experiences.

\section{PPPs in Water Infrastructural Development}

Across the globe, desire for utilizing PPPs in public infrastructural development is gaining momentum ever than before largely to compensate government failures in delivering public essentials adequately. In the view of Asian Development Bank Institute (ADBI) (2011:4) in the last decade there has been an important increase in the use of public private partnerships; the driver being limited public funds coupled with an increasing acceptance that private sector is often better placed to handle many of the traditional tasks of the public sector.

Evidence on the ground generally points high uptake of PPPs in public infrastructure as immediate solutions to addressing perennial challenges by most governments in infrastructure networks in their respective countries as well as enhancing quality services delivery (Farlam, 2005:1). Majority of them are optimistic that applying PPPs model; in which government shares risk and responsibility with private partners, but ultimately retaining control of assets will go a long way in improving services, and concurrently avoiding some of the pitfalls of privatization: unemployment, higher prices and corruption. Particularly in the water sector, the concept of PPP can never be underestimated. According to Marin (2009:1) many governments in the 1990s embarked on ambitious reforms of their urban Water Supply and Sanitation (WSS) services that often included delegating the management of utilities to private operators under various contractual arrangements. Hopes were high that PPPs would turn around poorly performing public utilities by bringing new expertise, financial resources and a more commercial orientation. As has been widely argued in literature, the concept of PPPs can never be ignored as remedial actions towards government failures in undertaking its sovereign duties especially in this context of limited fiscal space and rapid urbanisation and population explosion. According to Jerome (2004:20), the constant malfunction of African governments to deliver basic goods and services to the general population is well documented but not remedied. Governments in the developing world operate in an environment of limited fiscal space and thus lack resources for maintenance and upgrading of existing infrastructure. This is largely because government utilities are facing problems of low productivity, poor cost recovery strategies, political interference and general lack of transparency (Bailis and Hall 2000, Zhou 2012:34, Jerome 2004:6; World Bank 2007:23).

Harris (2003) further added problems of inefficiency, deprived pricing strategies, and corruption as major deterrence to effective service delivery in the public sector. This is 
buttressed in (Faulkner 1995), who revealed water supply and waste management in African countries have been the responsibility of public organisations. However these entities without the support of the private sector cannot meet increasing demands for service delivery. In fact, they lack the funds to improve and develop services. It is further argued these public utilities do not only experience challenge in identifying and affording new, eco-efficiency technology; but also lack the skill to manage the services efficiently.

What should be born in mind is that a commonality in all PPPs arrangement; where a private consortium contracts with a public sector agency to finance, design and construct (or refurbish) a facility under a time and cost-specific contract. Following construction, (usually by consortium) services are then provided under a long-term contract and more often than not, a revenue stream is used to repay debt, fund operations, deliver contracted services and provide a return to investors (Linda 2006:253). In fact, PPPs are one form in the range of procurement options that are available for public infrastructure. In fact, PPPs are recognised of the contemporary significance of addressing mounting public infrastructural commitments across the globe. In this case, the fundamental characteristic of a PPP is the involvement of the private sector in the delivery of a public infrastructure project and/or public services. It is further argued that the participation of the private sector in such projects, for instance, may encompass responsibility to build, own and operate an asset, while others may extend the arrangement to the transfer of the asset back to the government after a specified period, and often at no cost (World Bank 2007:23). Equally important the contract may entail public sector assuming ownership of the asset on completion and leasing it back to the private provider (Ibid:13). In support of this, Farlam (2005:2) suggests the need for government to essentially improve their relations with private actors to realise benefits these partnerships can provide.

This is because the private sector arguably bristles with dynamics, creative in a world of entrepreneurialism, unlike the corrupt, "lazy" strike prone workers in the public sector (Farlan, 2005:05). In addition, studies from UK where Private Finance Initiative (PFI) was, demonstrated that cost savings by private organisations providing public services changed the terms of employment thereby reducing the costs in service provision. Therefore, the gains and benefits PPPs cannot be underestimated and must be considered carefully by governments. The reasons for privatisation are based on the generalisation that the private sector performs better than the public sector. Implied is that PPPs offers opportunity to overcome inefficiency and wastage that characterise the public sector (Ibid).

In this regard, Farlan (2005:06) concludes that the fiscal benefits from sale or lease of state-owned enterprise (SOEs), including reduced subsidies to these often loss-making entities, or new investment government cannot afford to provide on its own. He further added that there is also the efficiency gain of the private sector which can lead to lower prices and improved access by more of the population, the development of local financial market and increased private sector development which includes broadening local participation. In addition, PPPs is often regarded as an aid conditionality of donor agencies for developing countries (Ibid). 
ADBI (2011:4) suggests PPPs as viable avenue to steer up socio-economic growth. Given that PPPs are taken as engine for infrastructural development, economic and social development are arguably viewed as highly dependent on the development of infrastructure, especially in transport, and utilities such as water, power, and telecommunications. If these essential are made available for the public, it is strongly argued, this will resultantly improve social infrastructure for health and education as well as many other facilities. PPPs arrangement is also taken as enhancing government in tackling in key infrastructure deficits. In this case they are meant to finance long list of essential infrastructure projects which traditional governments, if left alone cannot invest in. Overall, the above author summarises the benefits of PPPs as follows: they provide additional capital; they provide better management and implementations skills. In this case private sector engagement in public sector activities may bring in performance benchmarking in order to achieve value for money; thus improving the quality of public service.

PPPs are also important as they promote more efficient allocation of risks (thus improving the identification of needs and optimal use of resources over the whole life of a project). This is because at the pith of PPPs lies the allocation of risk to the partner that is capable of managing it. If properly managed PPPs are strongly considered as "cash cow" for government in the long term. This can be largely due to argued increase in the level of quality and efficiency which can motivate users to pay user-charges; hence more profits. ADBI (2011) further argues that since most contemporary governments are facing severe fiscal challenges that more often than not have compromised capital expenditure, reliance on PPPs can fundamentally result in faster implementation of public infrastructure projects for the good of the public. This can be due increase in the incentives by the private sector to deliver on time and according to specifications. Risk of design and construction are transferred to the private sector; and payments are based on delivery and quality, or the need to charge user fees encourages efficiency and quality (Ibid). Faulkner (1995:159) opines that across contemporary developing societies, there is a critical need for discovering new avenues for funding, technological support and leadership. This justifies that the private sector is needed for its distinct technological, financial and management resources. This is evidenced with proven records for delivering goods and services efficiently, maintaining capital equipment at a high standard and its ability to quick decision making than public bureaucracies.

In this case PPPs which allows private partner involvement with government control will not only ensure high quality and efficient public service delivery; but securing the much needed high degree of public accountability, preservation of public ethos, protection of all section of society and underwrites the delivery of social and environmental, as well as economic benefits. This in turn is regarded as a missing link for sustainable development as well as purely financial goals. Therefore the concept PPPs, as hybrid of government and private sector, is strongly believed as a modern solution against loopholes associated with government (traditional monopoly in public service delivery attached to inefficient, poor quality services) and full privatisation (whose profit motive undermines public ethos in service delivery). 


\section{Theoretical Framework}

\section{The Public Choice Theory}

The researcher draws some theoretical guides from the public choice theory. The study of the public private partnerships in water infrastructural Development is conceptualised within the theory of Public Choice, Pioneered by Buchanan (1962) the theory involves the application of cataleptics of the science of exchanges. The theory entails the application of the rational choice model that is the application of economies to political science. The public choice theory regards the existing democratic arrangements as very poor predictors of citizens' preferences. Thus, it proposes the application of the market notions in public managements. The public choice theory is attached to the market notion of trading and competition. The theory is much related to the concept of power decentralisation as an opportunity to promote competitions among government agencies, Public Private Partnerships falls under this notions. Wright (1995:13) defined the public choice theory as an economic analysis of political institutions. Public Private Partnerships is a concept that is best understood through the public choice theory in that it promotes opportunities and competition between government and private sector. The private sector enters into partnerships with government on merit. The public choice theory is based on the assumption that the private sector led economic growth and development is more efficient both productive and allocative efficiencies (Buse and Walt 2002). The private sector is more dynamic resilient, creative innovative and vibrant than the public one. The theory, however, reveals the nature and characteristic of public officials as self seeking individuals, utility maximisers, individuals who seek to abuse public offices for personal gains implied is that government rarely acted in the public interest since they have their own embedded interest.

The public choice theory is, therefore, instructive to the study of the use of public private partnerships in the water infrastructural development in Zimbabwe in that it is a sub - field in economies and has developed an important and helpful perspective on non market behaviour and calls for reforms. In his remarks in 1986 after receiving his Nobel Prize, Buchanan argued that

"those of us who have helped generate the wide spread notion that self interest is an important political motivation, would be extremely irresponsible if we acquiesce in the influence that reform and construction are not possible... We need not jump back into the delusion that political agents are benevolent in order to think seriously about reform. We must, I think hold onto the faith that modern individuals can change the cause of their own history and in ways that are not predetermined by their economies of interest, whatever in the models of public choice or Marxism. To change history in the direction of a society that combines liberty of person, prosperity and order, modern men and women must be considered able to take a more comprehensive view than that measured strictly by their net wealth. It is time to again dream attainable dreams and to recover the faith that dreams can become realities (1986)."

The implication of the public choice theory vis-a-vis the preconditions of PPPs and some case study is that the theory calls for the application of economics to political science. Thus, it 
proposes the application of market notions in public management that is trading and competition. Preconditions of PPPs are enablers of competitions and inclusion of market tools in public management. Preconditions such as the legal and institutional frameworks, stable socio-economic and political environment, and respect of property rights, among others act as a link between private and the public sector. Countries such as South Africa, United Kingdom, and the Philippines among others have adopted the preconditions of PPPs and managed to match the theory and practice.

\section{Global Experiences of PPPs: Success and Failure Cases}

\section{South Africa Case Study}

The South African government embarked on PPPs soon after attaining its independence in 1994.It took an approach of reforming management of state assets (Department of Public Enterprises 2005a, Flinders 2005:216). PPPs in South Africa falls under the National Treasury which constituted a PPP unit in 2000 and this PPP unit plays a pivotal role in the creation of PPPs (Burger 2000:1).In April 1997 the South African cabinet appointed an inter-departmental taskforce to develop policy, legislation and institutional reforms to incorporate PPPs. Between 1997 and 2000, two pilot projects were carried out. By mid 2000 the PPP unit was established and the unit is regulated in terms of Treasury Regulation 16 issued in 2004 to the Public Finance Management Act (1999). The water PPPs in South Africa started in 1992 in Queens Town and Malute and the population served is 0, 6 million (Marin 2009).In 2000 a water PPP project was commissioned in Emfuleni. The project was called the WRP-Metsi-a-LekoaSebokeng-Evaton Leakage Reduction PPP Project. The project covered 70000 households. The project was necessitated by the general deterioration of the infrastructure. Metsi-a-Lekoa did not have the financial capacity to rehabilitate the infrastructure. The project was carried by WRP private limited (Dube and Chigumira 2011:17). The municipality did not contribute any financial input including initial capital cost. The total cost of the project was SAR10 million.

The World Bank (2007:78) argues that the regulation 16 of the Public Finance Management Act (PFMA) established South Africa's National Treasury PPP unit in 2000 as a filter to exclude fiscally irresponsible PPP transactions. The evolution of a PPP unit in South Africa was motivated by the treasury concerns over a specific PPP transaction proposed by the ministry of Public Works. This was a procurement of a BOT contract for two prisons. Ibid further alludes that the PFMA Regulation requires that every PPP agreement, must be affordable for the government, show value for money, transfer substantial technical operational and financial risk to the private partner. The regulation 16 requires formal treasury approval for each PPP unit at four stages. These stages include completion of feasibility study. This is done to ascertain the affordability of the PPP and consistence of costs in line with the budget. The second stage is at the completion of bids documents. The selection of bidders is the third stage and the fourth and final stage the finalization of the PPP agreement. The Treasury PPP unit has been credited for 13 deals worth us $\$ 300$ million dollars. 
Most deals successfully concluded by the South African PPP unit include transport, health care, information technology. According to the World Bank (2007:80), the treasury PPP unit in South Africa managed to achieve its objectives. Former South African Finance minister in his speech in 2004 concluded that, "This is what PPPs are about. The public gets better, more cost effective services; the private sector gets new business opportunities. Both are in the interest of the nation". The prerogative of the South African PPP unit is to ensure that PPP agreements comply with the legal requirements of affordability, value for money and sufficient risk transfer (Burger 2006:9). The PPP unit guide government departments and provinces to achieve world standards best practices. Grimsy and Lewis 2005; Goosling 2004; Hodge 2004; Fourie and Burger 2000 concurs that successful PPPs must include affordability, value for money and sufficient risk transfer. The South African constitution provides that "when an organ of state contracts for goods or services it must do so in accordance with a system which is fair, equitable, transparent, competitive and cost effective".

\section{The United Kingdom (UK) Case Study}

So much has been written about the (UK) treasury PPP unit and Partnerships UK. Since 1996 the UK has been running an active PPP Unit World bank (2007: 87). Under John Major's Conservative government, the private finance initiative (PFI) was used for a variety of infra structure sectors through a Design Build Finance Operate (DBFO) model. Tony Blair's labour government changed the focus and re branded the programme as 'Partnerships UK' although both names are still being used. The UK has a separate PPP policy and project development agencies (World Bank 2007:87). Partnerships UK advise government agencies on PPP projects for a fee. Major achievements were made by the Partnerships UK. Since 1996 roughly seven hundred projects worth USD $\$ 80$ billion have been closed. New projects worth USD $\$ 8$ billion or 0,4 percent of Gross Domestic Product (GDP) was established the same year. The UK's PFI PPP activities between 1994 and 2005 represented two thirds of all European activities (World Bank (2007:87). Ibid further alludes that 80 percent of PFI projects were delivered in time and on budget.

\section{The Portugal Case Study}

Portugal embarked on its first PPPs in the 1990s to improve its infrastructure. In 2003 an audit on PPPs was carried and discovered that PPP liabilities amounted to ten percent of its GDP. In 2003, the government enacted a Decree Law number 86/2003 that defined the general rules relating to government intervention in design, conception , preparation, tender, adjudication, modification, auditing and global surveying of PPPs. The law sets minimum requirements for PPPs. Parpublica SA, a company owned entirely by the treasury was mandated with the responsibility of enforcing Decreto Lei No. 86/2003 by Despacho Nomativo 35/2003 It is estimated that, Portugal closed USD $\$ 10-12$ billion in PPPs between $2004-2005$ (Price Water House Coopers 2005). Portugal had the biggest PPP activity in Europe and constituted 10 percent of all closed deals in Europe. Most of the PPPs in Portugal concentrated on transport water and waste water sector (World Bank 2007: 83).

NB: It is worth noting that in Europe the European Commission had its own PPP guidelines. Price Water House Coopers (2005) highlighted that European countries that include Austria, 
Ireland, Netherlands and United Kingdom have very active PPP units. Denmark, France, Germany, Italy, Portugal, Cyprus, Czech Republic, Hungary, Latvia, Lithuania, Malta, Poland, Bulgaria and Turkey have PPP units which are in progress. Ireland, Spain, Turkey, Poland and Latvia have comprehensive PPP legislation in place, while Belgium, France, Greece and Romania have comprehensive legislation being drafted. The European Commission's guidelines for PPPs include the directive 2004/17/EC of the European parliament and the council of 31 March 2004. It coordinates the procurement procedures of entities operating in the water energy, transport and postal services (30.04.2004). Directive 2004/18 EC of the European parliament and of the council of 31 March 2004 on the coordination of procedures for the award of public works contracts, public supply contracts and public service contracts (30.04.2004)

Commission Regulation (CR) No. 1564/2005 of 07 September 2005 establishing standard forms for the publication of notices in the framework of public procurement procedures pursuant to Directives 2004/17/EC and 2004/18/EC of the European Parliament and of the council. However the decision to use or not to use the European Commission guidelines lies within European member states, although the European Union finances PPP projects through the European Investment Bank.

\section{Australian Case Study}

Partnerships Victoria was established in 1980. The aim was that of UK and Portugal which intended to push and expenditure off the books (World Bank 2007:89). The return of the labour government in1999 in Victoria under Steve Bracks influenced Partnerships Victoria on adoption and expansion of the previous PPP programme. Ibid further alludes that, the major focus was on risk transfer, maximising efficiency and minimising whole life costs. The treasury team is responsible for implementing the policy. As noted by the World Bank (2007:89), the Victoria's treasurer claimed that "Australia is now the second most developed PPP market in the world after the UK". Its projects include Spencer Street Station in Melbourne, re development of the Melbourne show grounds, a new convention centre, a major new court building and a number of water treatment works and accommodation projects. Partnerships Victoria was established in 1980. The aim was that of UK and Portugal which intended to push and expenditure off the books (World Bank 2007:89). The return of the labour government in1999 in Victoria under Steve Bracks influenced Partnerships Victoria on adoption and expansion of the previous PPP programme. Ibid further alludes that, the major focus was on risk transfer, maximising efficiency and minimising whole life costs. The treasury team is responsible for implementing the policy. As noted by the World Bank (2007:89), the Victoria's treasurer claimed that "Australia is now the second most developed PPP market in the world after the UK". Its projects include Spencer Street Station in Melbourne, re development of the Melbourne show grounds, a new convention centre, a major new court building and a number of water treatment works and accommodation projects.

\section{The Philippines Case Study}

The Philippines has its BOT Centre and the PPPs were first muted in the 1980s and gained 
momentum in the 1990s. In 1997 President Corazon Aquino issued an Executive Order (EO) 215 EO 215 gave a green light to private operators to provide power. On take or pay basis. In 1991 the Republic Act (RA) No. 6957 also known as Build Operate and transfer (BOT) was enacted and amended in 1994 as RA No 7718 to provide a frame work from private sector investment in infrastructure. The BOT Law regulates national and local government PPPs and other sectors. The Executive Order (EO) 144 was reorganised and converted the coordinating Council of the Philippines Assistance Programme (CCPAP) and its secretariat to the BOT centre and transferred the Coordinating Council for Private Sector Participation (CCPSP)'s attachment from the office of the President to the Department of Trade and Industry (World Bank 2007:91). The BOT centre assisted in sixty transactions worth USD \$18 billion. The Manila Water Works and Sewerage System (MWWSS) was privatised at a value of USD $\$ 7$ billion. The Water Concession Maynilad Water Concession was won by Suez Subsidiary Ondeo in 1997. The two Concessions in Manila deserve special attention because they represent the largest population served by private operators in developing world (Marin 2009:114).

\section{Research Methodology}

The research used a case study approach. By taking potential use of PPPs in water infrastructural development in Harare City Council as a case study, the research had an in-depth study in terms of prerequisites, benefits and challenges in order to have a grand generalisation on Zimbabwe's preparedness to embrace PPPs in water infrastructural development.

The target population was drawn from individuals, organisations and social artefacts. Individuals including the academics, think tanks, directors in the Harare City Council and the Ministry of Finance, the Ministry of Local Government, Office of the President and Cabinet, Department of Public Works. Organisations include Zimbabwe National Water Authority (ZINWA), Zimbabwe Economic Policy Analysis and Research Unit (ZEPARU), African Capacity Building Foundation (ACBF), Water Net, United Nations Children's Emergence Fund (UNICEF). Social artefacts take the form of books, journals, newspapers and reports. (Burns and Grove (1997:236) define target population as "the entire aggregation of respondents or subjects that meet the designated set of criteria.

\section{Sampling Procedure}

Purposive sampling was used to select a total of twenty (20) key informants who include two (2) senior lecturers (academics) from the University of Zimbabwe in the Department of Political and Administrative Studies, two(2) directors from the Ministry of Local Government Public Works and National Housing, two(2) directors from the Ministry of Finance, two (2) directors from the Office of the President and Cabinet, two (2) representatives from UNICEF, two(2) directors from ZINWA, two (2) directors from ZEPARU, two (2) directors from Harare City Council, one (1) director from (ACBF), two (2) directors from the State Procurement Board and one (1) director from WATER NET. 


\section{Documentary Search}

The documentary search was on preconditions of PPPs, experiences and challenges of PPPs in Zimbabwe, policy and implementation levels. Pre-requisites of PPPs literature form the bedrock of research by providing the comprehensive data that was used to assess Zimbabwe's preparedness to embrace successful PPPs.

Relevant pieces of legislation governing PPPs, constitutions, blue prints, mid-term policies, feasibility studies, draft policy documents, national budget statements, Ministerial Statements, Parliamentary debates among others, were used. Implementation level literature to review tangible benefits of PPPs in water infrastructural development included relevant survey reports, by government, academia, Non-Governmental Organisations (NGOs), UNICEF, relevant Newspaper articles, websites, media reports, book material, journals as well as unpublished materials.

\section{Key Informant Interviews}

Key informant interviews were conducted with two directors from the Ministry of Finance, two directors from the State Procurement Board (SPB), two directors from the Ministry of National Housing and Public Works, one director from the Office of the President and Cabinet, two directors from the City of Harare, two senior lectures from the University of Zimbabwe's department of Political and Administrative Studies, two directors from ZINWA, two directors from UNICEF, two directors from ZEPARU, one director from ACBF and one director form Water Net. This method was used to gain a comprehensive understanding of the potential use of PPPs in water infrastructural development

\section{Data Presentation and Analysis}

\section{Benefits of PPPs}

Question one (1) seeks to identify whether the respondents were of the view that PPPs can be helpful in the provision of water infrastructure in Zimbabwe's local authorities. All of the 20 respondents concurred that PPPs are a panacea to water infrastructure development in local authorities. A further probe on the same question about the virtues of PPPs and models preferred indicated that most of the respondents were aware that government is faced with a challenge of limited fiscal space. The problem is compounded by the rapid dilapidation of water infrastructure especially in Harare. PPPs can help to source private sector funds to boost water infrastructure which include major dams around Zimbabwe. Respondents from the private sector and the University of Zimbabwe clearly gave a cocktail of advantages of using PPPs which include the ability of PPPs to make use of the private sector skills and financial resources to improve water infrastructure in time. PPPS improve service delivery at affordable prices; PPPs improve foreign direct investment in water infrastructure, creation of jobs to local people. For example, on construction of dams, sewerage works, among others. Respondents further alluded that PPPs brings certainty in long term planning by government injecting capital thereby reducing pressure from the government on infrastructure development especially water. PPPs in water infrastructure benefits indigenous entrepreneurs through sub-contracting in infrastructure development. PPPs allow risks to be allocated to the 
party best able to manage or absorb them. Information gathered from desk research collaborates very well with the same information given by the respondents on the benefits. Farlam (2005:1) argues that evidence on the ground generally points high uptake of PPPs in the public infrastructure as immediate solutions to addressing perennial challenges faced by most governments in infrastructure networks in their respective countries as well as enhancing quality service delivery. Jerome (2000:20) further alludes that, the constant failure of African governments to provide adequate services to their people is well documented and can only be remedied through PPPs. Mann (2009:1) highlighted that many governments embarked on PPPs in the early 1990s in urban water supply with high hopes of turning around poorly performing public utilities by bringing the new expertise, financial resources and a more commercial orientation. The Zimbabwe Agenda for Socio-Economic Transformation also gave an impetus to the use of PPPs in water infrastructural development. On page 2 and 3 the ZimAsset document categorically indicates that water and sanitation infrastructure must be rehabilitated and the strategy to achieve that is the adoption of PPPs. In his maiden speech on the official opening of the $8^{\text {th }}$ session of Parliament, President Mugabe highlighted that PPPs were a way to go. Basing on the data collected from the respondents and documentary evidence, the benefits of PPPs are indisputable.

\section{Zimbabwe's Readiness}

All the respondents indicated that Zimbabwe is not ready to embrace PPPs in water infrastructure development. Although Zimbabwe has already engaged PPPs with a Chinese company to rehabilitate the water infrastructure in Harare City Council, data solicited from the city council indicate that confusion shrouds the PPP deal due to lack of a legal framework and an institutional framework.

Corruption continues to hinder PPP uptake through underhand deals, inflation of prices if there is no proper legal framework. Respondents from the Harare City Council indicated that although the deal is a PPP project, there are no clear rules and regulations in place. Respondents from the University of Zimbabwe attributed that Zimbabwe is not ready because of its lack of political will especially to involve the Western countries of which the political leadership declared western countries enemies. The other reason why Zimbabwe is not ready according to respondents at the University of Zimbabwe is that Zimbabwe is under sanctions from the western powers and hence private players from those countries are forbidden through instruments such as Zimbabwe Economic Recovery Act (ZIDERA) 2001 adopted by the United states of America.

Respondents from a think tank ZEPARU revealed that Zimbabwe is not ready for PPPs because its PPPs policy guidelines of 2004 which sought to provide the parameters for the development of an appropriate legal and regulatory framework never really took off. Although some PPP projects were carried out in Zimbabwe, they were implemented on an ad hoc basis without proper evaluation of success or failure.

Without the proper legal and institutional framework, all the PPP projects that were implemented in Zimbabwe through the BOT model used statutes such as the Procurement act Chapter 22:15 and the Income tax Act Chapter 23:06. One respondent from the Ministry of 
finance indicated that there is currently no legislation, policy or institutional framework that pertains to PPPs specifically in Zimbabwe. Currently, there are efforts to enact new PPP legislation in Zimbabwe. In addition respondents from the Ministry of Finance clearly indicated that the concept of PPP legislation is shrouded in confusion. They professed ignorance about which institution is responsible for PPPs. They indicated that the Public Accounts Committee has a hand which is obscure.

Key informants from the African capacity Building Foundation (ACBF) agrees that Zimbabwe is not ready for PPPs because the country lacks political commitment, legal framework, lack of finance, lack of monitoring and evaluation, lack of legislation, among others. The data gathered from the interviews concurred with data gathered from literature. Dube and Chigumira (2011:3) in their ZEPARU working paper clearly highlighted that Zimbabwe is yet to adopt a PPP legislative framework. Further, data gathered from a Zimbabwean PPP Legislative Review (2010) argues that there is no appropriate legal and regulatory framework. Honourable Hebert Murerwa the then Acting Minister of Finance was quoted as saying; "these guidelines also provide the parameters for the development of the appropriate legal and regulatory framework".

From the evidence gathered from the respondents and documentary evidence, it is apparent that Zimbabwe is not ready for successful implementation of PPPs in water infrastructure. There is no adequate legal, institutional framework to deal with PPP especially in water infrastructure. Countries such as South Africa, the United Kingdom, among others have well established PPP units. In 2004 the South African government established its PPP unit regulated in terms of Treasury Regulation 16 issued in 2004 to the Public finance Management Act (1999). The UK Treasury PPP unit and partnerships dates back to 1996. Compared to other countries which have well established PPP units, Zimbabwe's readiness to embrace PPP units in water infrastructural development remains low note.

\section{Effectiveness of Zimbabwe's current PPP framework}

Data collected from most key informants alludes that the PPP de-facto laws can be traced back to the Policy Guidelines of 2004. Further, the short term economic recovery programme (STERP) of 2008 tried to invite the private sector to participate in the provision of infrastructure on a PPP basis. It offered dispensations and privileges to private sector. Despite all the promises, the Guidelines are ineffective. Short Term Economic Recovery Programme (STERP) was superseded by Zimbabwe Agenda for Socio Economic Transformation (ZIM ASSET) which is yet to produce results. Key informants from the University of Zimbabwe argued that there is no framework that relates to water PPPs. Respondents from the Office of the President and Cabinet (OPC) alluded that, the current framework is working and is institutionalised within the ministry of finance. The ZIM ASSET blue print on page 52 and 53 highlighted that water and sanitation infrastructure will be rehabilitated through the adoption of PPPs. It remains to be seen how Zimbabwe will embrace successful PPPs without a proper legal and institutional framework.

Respondents from the University of Zimbabwe's department of Political and Administrative studies argue that, there is no evaluation on the projects done through PPPs to measure 
success. It is however difficult to tell effectiveness under such circumstances

Key informants from the ministry of Finance, think tanks, the University of Zimbabwe in the Department of Political and Administrative Studies concurred that the current statutes that govern PPPs in Zimbabwe are unclear and ambiguous. They further alludes that there is no legal framework that govern PPPs.

Senior government officials from the Office of the President and Cabinet (OPC) and Ministry of Local Government highlighted political willingness on the part of the government. Some think tanks argue that, there is generally lack of political will to enact legal and institutional frameworks that govern PPPs in Zimbabwe. They further argue that politicians deliberately cripple the implementation side for their self aggrandisement. The debate of political will is still confusing in Zimbabwe. One would wonder whether public pronouncements as simply rhetoric or serious business on the part of government to embrace PPPs, $80 \%$ of the respondents concurred that there is no institution responsible for PPPs in infrastructural development. Documentary data collected from the Public Private Partnership: Legislative Review for Zimbabwe (2010:5) also revealed that the policy guidelines document (2004) was adopted as a basis to a legal and regulatory framework being put in place. Ibid further elaborates that currently PPPs in Zimbabwe can be done under the procurement Act.

Data gathered from respondents from the Ministry of finance reveals that the proposed legal and institutional framework is an idea spearheaded by the former Deputy Prime minister's office during the inclusive government. Efforts are still under way to make an act.

\section{Pre-requisites of PPPs in Water Infrastructure Development.}

All the key informants concurred that the legal and institutional frameworks are key preconditions for successful implementation of PPPs. Implied here under the legal framework is the Creation of an Act of parliament that should be in the Constitution on PPPs. Key informants from the university's Department of Political and Administrative Studies further alludes that, that Act of parliament must supported by a statutory instrument that operationalise the constitution provision. Key informants in the form of think tanks allude that the PPP policy must be supported by PPP Guidelines including standardized contact terms. Further, that Guidelines should cover important areas such as appointment of transaction advisors, completing a feasibility study, risk assessments and contract management among others. Key informants from the Ministry of Finance also add weight on the creation of a PPP Act. In their view a PPP Act will provide for the establishment of a PPP Unit. The PPP Act will become a dedicated legislation. According to ADB (2011) the legal, regulatory and policy frameworks presents a bench mark for establishing PPPs. The legal frameworks helps in establishing the legal reforms needed to reduce impediments to improved or expanded service such as financing, regulating and managing infrastructure assets (Ibid).

According to the World Bank (2007:91) Philippines enacted its PPP law known as the Republican Act (RA) No.6957 also known as the BOT. The law was again amended in 1994 as RA No. 7718 to provide a framework for private sector investment in infrastructure. 


\section{I Macrothink}

From the foregoing deliberation, it is paramount to not that the legal frame work provides the basis for successful implementation of PPPs. Data collected from the key informants generally points to the legal framework as a bedrock for successful PPPs.

The success of the PPP process hinges on the presents of a PPP institution to oversee the PPP process (Dube and Chigumira, 2011:23). Key informants from the University of Zimbabwe's department of Political and Administrative studies alluded that as a prerequisite, institutionary that run PPPs must established. According to the Word Bank, these institutions in other countries are called PPP Units. They play a supportive role. According to the draft policy document of (2010:15) the successful roll out of PPPs in Zimbabwe requires institutional framework. The draft policy document of (2010) further gave a summary of roles of such institutions which include:

(a) Identifying and submitting the proposals for PPPs to the unit.

(b) Engaging Transaction advisors to assist with feasibility studies.

(c) Procuring such PPP and liaison with the State Procurement Board.

(d) Evaluating and selecting the preferred bidders in liaison with the SPB.

(e) Negotiating and awaiting the contract.

(f) Implementing and managing PPP projects. The institutions will be intimately involved with the project throughout its life time in order to achieve the objectives of the project.

According to the Draft PPP Document 2010 the role of the PPP Unit as an institution is to advocate for PPPs and to give technical support. It can be summarised as follows:

a) To coordinate and harmonise the implementation and review of the PPP programme.

b) To ensure there is enabling legislature environment for PPPs.

c) To ensure the guidelines and procedures for PPPs are followed.

d) To ensure the advancement of social and economic goals of Zimbabwe.

e) To recommend approval of PPP projects to the Cabinet.

f) To advise Government and assist on technical issues related to PPPs.

g) To act as the repository of information on PPPs in Zimbabwe.

h) To promote the PPP concept among domestic and international investors and the general public.

Data gathered from key informants and documentary evidence suggests that there should be an institutional framework as a prerequisite for full successful implementation of PPPs.

Other prerequisites include the much talked about that is the political will to engage private partners, economic stability, respect of property rights, financial support, technical expertise 
and government commitment among others. Key informants from the Ministry of Finance gave much input on the above preconditions as enabling factors in order for Zimbabwe to embrace the concept of PPPs.

\section{Readiness of Zimbabwe's local authorities to implement PPPP}

All the respondents concur that if the country is not ready then an institution cannot be ready. Evidence given on question 2 on Zimbabwe's readiness suggests that even the local authorities are not ready to embrace PPPs. In addition, the current PPP project being carried out at Morton Jeffry water works opened a can of worms. The Herald of 5 February, 2014 published a story entitled "City officials loot US100 million by Farirai Machivenyika. That is an indication that the local authority is not ready to embrace successful PPPs in water infrastructural development. See pictures cutesy of the Herald.

\section{Challenges hindering effective PPP Implementation}

Data collected from key informants, points to lack of legal and institutional framework that govern PPPs in Zimbabwe. Key informants from think tanks alluded that lack of political will, duplication of roles, lack of financial capacity, lack of expertise, unconducive economic environment, unpredictable laws, country risk among others are some of the challenges that hinder effective implementation of PPPs in Zimbabwe. On the other hand key informants from the Ministry of Local Government and Public Works blamed it all on illegal sanctions as a major challenge because investors from foreign western countries are restricted to do business with Zimbabwe. Another key informant from the University of Zimbabwe highlighted that corruption is another challenge. The respondent gave an example of the PPP project which he better known as the Chisumbanje ethanol project. That PPP deal according to the source is allegedly shrouded in corrupt deals by high ranking government officials. Another example is the current Sino Zimbabwe PPP deal which again according to the Herald is already infested with massive corrupt activities. The other challenge according to the Ministry of Finance is that of the country's international debt. Currently, Zimbabwe's international and domestic debt stands at US10 billion of which the government should act as a guarantor in PPP projects. This deters would be investors.

According to the draft PPP document of 2010 challenges such as process risk, complex enforcement of contractual obligations, conflicting interest between the public and private sector, lack of finance, lack of expertise are some of the key challenge hindering effective implementation of PPPs in Zimbabwe. Key informant from African Capacity Building Foundation (ACBF) argues that inconsistencies on the part of government are another challenge. He gave an example of initiatives made by the Deputy Minister's office linked to STERP then followed by ZIM Asset which is silent on legal and institutional framework and the office has been disbanded. This is a clear Zimbabwean fashion and it makes it difficult for continuity, the source said. This is supported by Dube and Chigumira (2011:3) who argues that Zimbabwe's PPP idea was mooted in 1998 and the first framework was attempted in 2004 and the guidelines never really took off. Apparently Zimbabwe is facing a myriad of challenges for it to fully embrace succe4ssful implementation of PPPs basing on the evidence on the ground. 


\section{Macrothink \\ Journal of Public Administration and Governance \\ ISSN 2161-7104 \\ 2015, Vol. 5, No. 1}

\section{Efforts made to circumvent the challenges}

Think tanks have written fully researched documents, full of recommendations which are at the government's disposal for consideration, for example, ZEPARU published a book titled "The scope for PPPs for Infrastructure Development in Zimbabwe. Key informants from the Office of the President and Cabinet also gave their account that, the office of the former Deputy Prime Minister made great strides by coming up with a draft document of 2010 on PPPs. The draft document is currently circulating in parliament and it is up to the Government to either approve it or reject it.

If the DB draft is accorded its status, Zimbabwe will mitigate all its challenges and become champions in embracing PPPs successfully. Key informants from the OPC argue that Zimbabwe had made efforts to meet its challenges by refining institutional framework in 2004. The variable institutional parties involved are spelt out with their roles and functions as well as reporting structures. Despite efforts made by the government to meet challenges in embracing PPPs, these efforts are not adequate.

\section{Conclusions and Recommendations}

\section{Conclusions}

The study was set to establish Zimbabwe's potential use of PPPs in water infrastructural development. The study established that Zimbabwe is not ready to fully embrace PPPs. The country does not have the prerequisites necessary for successful implementation of PPPs which are not limited to the following, legislative framework, institutional framework, established PPP Unit. The study further established that political will; socio economic and political factors complicate Zimbabwe's readiness. Benefits associated with PPPs were established and government should fulfil the preconditions necessary for successful implementation of PPPs.

\section{Summary of major findings}

- Zimbabwe is not yet ready for successful implementation of PPPs.

- The major preconditions of PPPs are legal and political framework.

- Zimbabwe's current PPP institutional framework is not conducive.

- PPPs have more benefits if fully implemented.

- The current socio-economic and political environment in Zimbabwe is not conducive

for effective PPPs implementation.

- Zimbabwe does not have what it takes in order to fully embrace successful PPPs in water infrastructural development.

\section{Measures to fully engage PPPs}

The study established that the country should adopt a proper legal and institutional 
framework. There should be generally a political will to attract foreign direct investment. Economic sanctions should be removed in order for the country to attract investors. The country's debt should be cleared so that confidence from the private sector can be restored.

\section{Recommendations}

Zimbabwe should put into effect the legal and institutional framework that should act at a springboard for foreign direct investment. The country should fast track the finalization of the PPP policy and institutional framework. The creation of the PPP policy should enhance the creation of a PPP Unit that should work within the Ministry of Finance and Economic Planning. For example, the South African Government established a PPP unit regulated in terms of Treasury Regulation 16 issued in 2004 to the Public Finance Management Act (1999), World Bank (2007:78).

Zimbabwe should mobilize sources for the PPP unit. The country should fight corruption in order to attract local and foreign investment. PPPs require open and transparent business transactions especially in awarding of tenders and the pricing of services and commodities. This should be done by technical experts who have the constitutional mandate to do the job. Zimbabwe should engage the International Monetary Fund and the World Bank in order for it to access its line of credit. Further the country should accelerate its debt clearance in order for it to gain the confidence of moneylenders both domestic and external money lenders and built investor confidence. Furthermore the country should work towards the removal of economic sanctions that blockade foreign direct investment especially from the western countries.

Finally this study recommends that Zimbabwe should improve its socio-economic and political environment as well as respect of property rights. PPPs require consistent laws and a stable economic and political environment to carry long term projects such as BOTs among others and allay the fears of investors.

PPPs as an intervention produce encouraging results. The Government should seriously engage PPPs as an intervention to water infrastructural development. This concurs with bribe and Chigumira (2011:27) who argue that PPPs can indeed help especially at a time like now where the Government is financially handicapped.

\section{Bibliography}

ADB. 2005. Public-Private Partnership Handbook.6 ADB Avenue, Mandaluyong City

1550 Metro Manila, Philippineswww.adb.org Publication Stock No. 071107.

ADBI. 2011. Appropriate Financial Instruments for Public-Private Partnership to Boost Cross-Border Infrastructural Development-EU Experience. Kasumigaseki Building 8F 3-2-5 Kasumigaseki, Chiyoda-ku Tokyo 100-6008, Japan.

Babbie, E.R. 1986. The Practice of Social Science Research. Belmont: Wardsworth Publishers. 
Babbie, E.R. 2010. The Practice of Social Science Research. California: Cengage Learning.

Bayliss, Kate and David Hall (2000) Independent Power Producers: A Review of the Issues A PSIRU Report for PSI http://www.psiru.org/reports/2000-11-E-IPPs.doc.

Blackburn, K. and M. Christensen. 1989. "Monetary Policy and Policy Credibility: Theories and Evidence."Journal of Economic Literature XXVII.

Burnett, M. 2007. Public-Private Partnerships (PPP) - A Decision Maker's Guide. European Institute of Public Administration (EIPA).

Burns, N and Grove, S.K. 1997. The practice of nursing research: Conduct, Critique and Utilization. 3rd edition. Philadelphia: Saunders.

Claire, S. (1959). Research Methods In Social Relations. U.S.A: Holt, Rinehart and Winston.

Colman, J. "Examining the Value for Money of Deals under the Private Finance Initiative/Public Private Partnership." Public Policy and Administration 15, no. 4 (2000): 72-82.

Dube, C. and Chigumira, G. 2011. The Scope for Public-Private Partnerships for Infrastructure Development in Zimbabwe. Harare, ZEPARU.

European Commission. 2003. Guidelines for Successful Public-Private Partnerships. March 2003, Directorate-General for Regional Policy.

Farlam, P. 2005. Working Together Assessing Public-Private Partnerships in Africa. The South African Institute of International Affairs.

Government of Zimbabwe (2012) Budget Statement, Harare, Printflow.

Government of Zimbabwe (2013) ZIMASSET, Harare, Printflow.

Government of Zimbabwe PPP Draft Document (2010), Harare, Printflow.

Guion, L.A., Diehl, D.C., and McDonald, D. 2011. Conducting an In-depth Interview. University of Florida.

Harris, C. 2003. Private Participation in Infrastructure in Developing Countries: Trends, Impact and Policy Lessons. Washington DC: World Bank.

Hodgson, G., 1988. Economics and Institutions. Polity Press, Cambridge. 'The approach of institutional economics', Journal of Economic Literature, 36(1):166-92.

Holsti, O.R. 1968. "Content Analysis", in The Handbook of Social Psychology, ed. Gardner Lindzey and Elliot Aronson, Reading, Mass: Addison-Wesley.

Lane, P. 1993. Anatomy Of A Public-Private Partnership. Center for Real Estate Quarterly Report, vol. 7, no. 2.

Linda, E., 2006. PPPs in Australia: An Overview of their Nature, Purpose, Incidence and Overview. Journal of UNSW Law Vol 29(3) 250-262. 
Moszoro, M. and Gąsiorowski, P. 2008. Optimal Capital Structure of Public-Private Partnerships.International Monetary Fund WP/08/1.

Marin, P., 2009. PPP for Urban Water Utilities: A review of Experience in Developing Countries. Washington DC: World Bank.

PPIAF (Public-Private Infrastructure Advisory Facility). 2002. "Emerging Lessons in Private Provision of Infrastructure Services in Rural Areas: Water and Electricity Services in Gabon." PPIAF and the World Bank, Washington, DC.

Renda, A. and Schrefler, L. 2006. Public-Private Partnerships-Models and Trends in the European Union. Brussels, European Parliament.

Sawyer, M. 2005. The Private Finance Initiative: The UK Experience. In Procurement and Financing of Motorways in Europe. Research in Transportation Economics. No. 15, Elsevier.

OECD. 2008. OECD Principles for Private Sector Participation in Infrastructure. Paris: OECD.

Polit, D.F and Hungler, B.P. 1995. Nursing research: Principles and methods. 5th

Edition. Philadelphia: Lippincott.

Price-Waterhouse and Coopers. 2006. Hybrid PPPs: Levering EU funds and Private Capital. January 2006, PPIAF_-Public Private Infrastructure Advisory Facility.

Rice, P. and Azzy, D. 1999.Qualitative Research Methods: A Heath Focus. Melbourne: Oxford University Press.

Scott, M. 1990. Qualitative Evaluation and Research Methods ( $2^{\text {nd }}$ ed.). Newbury Park CA: Sage Publication.

Smith, W. 1997. Utility Regulators: The Independence Debate. Public Policy for the Private Sector Note No. 127. October. Washington, DC: World Bank. Available: http://rru.worldbank.org/Documents/PublicPolicyJournal/127smith.

Tellis, W. 1997. "Application of a Case Study Methodology." The Qualitative Report, 3 (3), 34-49.

Tongco, C. 2007. "Purposive Sampling as a Tool for Informant Selection: Research Methods." A Journal Plants, People and Applied Research, 3 (5), 147-158.

Vining, A., \& Weimer, D. (2005). Economic perspectives on public organizations. In D. Ferrin, L. Lynn, \& M. Pollitt (Eds.), Oxford handbook of public management (pp. 209-233). Oxford, UK: Oxford University Press.

Williamson, O.E. 1999. Public and Private Bureaus: A transaction cost perspective. Journal of Law, Economics and Organization15(1) 306-342.

World Bank. 2009. Attracting Investors to African Public-Private Partnerships: A Project Preparation Guide. Washington DC 20433. 


\section{Macrothink}

Journal of Public Administration and Governance ISSN 2161-7104

Wright, M.D.1993. A critique of the Public Choice Theory Case for Privatisation Rhetoric and reality. Toronto: University of Toronto Press.

Zhou, G. 2012. Fiscal Management In Zimbabwe. Department of Political and Administrative Studies, University of Zimbabwe.

ZIMSTAT. 2012. Census 2012: Preliminary Report. Harare: Government of Zimbabwe. 